\title{
An assessment of recreational bank angling in the Free State Province, South Africa, using licence sale and tournament data
}

\author{
LM Barkhuizen ${ }^{1,2^{*}}$, OLF Weyl ${ }^{3,4}$ and JG van $\mathrm{As}^{2}$ \\ ${ }^{1}$ Free State Department of Economic, Small Business Development, Tourism and Environmental Affairs, \\ Private Bag X20801, Bloemfontein, 9300, South Africa \\ ${ }^{2}$ Department of Zoology and Entomology, University of the Free State, P.O. Box 339, Bloemfontein, 9300, South Africa \\ ${ }^{3}$ South African Institute of Aquatic Biodiversity (SAIAB), Private Bag X 1015, Grahamstown, 6140 \\ ${ }^{4}$ Centre for Invasion Biology, SAIAB, Private Bag X 1015, Grahamstown, 6140, South Africa
}

\begin{abstract}
Recreational angling is an important form of utilisation of inland fisheries in South Africa but there is little information on this sector. The objective of this study was to provide an assessment of recreational bank angling in the Free State Province using licence sale and tournament data. During 2013 and 2014, 8256 and 7710 angling licences were sold, respectively. This represents a decline of $76 \%$ compared to the total licence sales in the Province in 1971. Tournament catch and effort data were obtained for 4796 tournaments that were held on 17 dams from 1974 to 2014. Reported tournament effort decreased by 67\% from 8548 tournament days in 1998 to 2828 days in 2014. Tournament catch composition was dominated by alien common carp Cyprinus carpio. Overall, this species comprised $81 \%$ of the weight and $77 \%$ of the number of fish landed during tournaments making it the most important angling species. The recent observed increase in subsistence angling could not be included in the analysis as participants are mostly not licensed. Alternative methods are therefore required if total catch and effort are to be estimated.
\end{abstract}

Keywords: recreational, fisheries, catch, effort, participation

\section{INTRODUCTION}

In South Africa, subsistence and recreational angling is currently the dominant form of utilisation of inland fisheries (Ellender et al., 2010a; McCafferty et al., 2012; Weyl and Cowley, 2015). This is anomalous in the African context as fisheries in other countries are generally heavily exploited by small-scale fishers using gears such as gill nets, seine nets and traps (Weyl et al., 2010; Cooke et al., 2013; Weyl and Cowley, 2015). Although inland fisheries in South Africa are generally considered underexploited from a harvest perspective (Weyl et al., 2007; Britz et al., 2015), case studies of angling on the Hartbeespoort Dam (Cochrane, 1987) and the Gariep Dam (Ellender et al., 2009, 2010a, 2010b) suggest that harvests by recreational and subsistence anglers can be considerable. Cochrane (1987), for example, estimated a mean annual harvest of 695 tons of fish from the 2000 ha eutrophic Hartbeespoort Dam by recreational anglers from the metropolitan settlements in Gauteng. In a more rural setting, Ellender et al. (2010a) estimated anglers harvested $88 \mathrm{t} \cdot \mathrm{y}^{-1}$ from the Gariep Dam, situated on the provincial boundary between the Eastern Cape and Free State Provinces. Ellender et al. (2010a; 2010b) demonstrated that this harvest contributed directly to the livelihoods of some 450 anglers whose primary motivation for angling was subsistence. Subsequent household surveys, in the rural settlements of Venterstad in the Eastern Cape and Hydro Park in the Free State, revealed that $56 \%$ of households contained at least 1 angler and that fish contributed significantly to the diet even in non-fishing households (Ellender et al., 2010b). In these non-fishing households, fish was purchased from anglers who sold their excess catch (Ellender et al., 2009). Ellender et al. (2010b) therefore recommended that the value of angling for communities near impoundments should be taken into consideration when developing inland fisheries. This is particularly relevant because there is increasing evidence that subsistence-motivated angling is becoming an important use of South African impoundments (Weyl et al., 2007; Ellender et al., 2009; 2010b; Tapela et al., 2015).

While South African inland fisheries are data-poor, data from angling tournaments are a valuable resource which can be used to derive preliminary angler catch statistics for fisheries (Hargrove et al., 2015). Some recreational anglers are members of angling clubs that are affiliated to the South African Sport Anglers and Casting Confederation (SASACC), an organisation which in 2016 represented 28433 anglers (SASACC, 2016). Members of angling clubs often take part in angling tournaments (Taylor et al., 2015). As one of the aims of tournament angling is qualification for a place on a provincial or national team, members are guided by, and must adhere to, the constitution, policies, rules and regulations of SASACC and, importantly, report their tournament catch data to the local conservation departments. In the absence of fishery independent survey data, these tournament data are a valuable resource that can be used to indicate the status of a fish stock and enable comparative assessments between fisheries (Hargrove et al., 2015).

\footnotetext{
To whom all correspondence should be addressed:

푱 Tel: +2751 400 4787; e-mail: barkhl@dteea.fs.gov.za Received 26 October 2016; accepted in revised form 20 June 2017
} 
Angling has a long history in the Free State Province. In an overview of recreational fisheries in 1963, Yates (1963) noted that there were limited angling opportunities due to the seasonal flows of the rivers and reported that the best angling was to be had in the rivers after rains, when carp Cyprinus carpio and yellowfish Labeobarbus spp. appeared in large numbers. With the construction of several large impoundments during the Orange River Development Project (ORDP), Opperman (1965) noted the vast potential that the project had for the development of fisheries in central South Africa. Indeed, inland fisheries are now of considerable interest because the Free State Province contains 412 impoundments, mainly located in the Orange and Vaal River basins, which cover a combined surface area of 147677 ha at full capacity. The potential for fisheries in these impoundments to contribute to economic development and food security is of interest to the provincial government. Unfortunately, the lack of formal monitoring of inland fisheries is a severe impediment to informed decision making (Weyl and Cowley, 2015).

Tournament catch data are available for public dams where access to public waters by anglers is controlled by the Free State Department of Economic, Small Business Development, Tourism and Environmental Affairs (FS DESTEA). This is because fisheries are managed according to the provisions of Nature Conservation Ordinance 8 of 1969 (NCO, 1969) and the Nature Conservation Regulations of 1983 (NCR, 1983) (see Table 1). Importantly, all recreational anglers in the Free State Province are required to be in possession of a valid angling licence. Angling tournament organizers are required to submit tournament results to the FS DESTEA within 2 weeks of the event. The aim of the current study was, therefore, to use licence sale data to obtain a first estimate of the number of recreational anglers and to use bank-angling tournament catch data to provide a detailed description of target species and catch rates by this sector in the Free State Province.

\section{MATERIALS AND METHODS}

\section{Study area}

The Free State Province covers an area of $129480 \mathrm{~km}^{2}$ and has a population of 2.8 million people (www.statssa.gov.za). The Province is situated centrally within the Orange-Senqu River Basin which is the most turbid river system in Africa (Compton et al., 2010) and the fourth most turbid river in the world (Bremner et al., 1990). Nearly 90\% of the land in the Province is used for agriculture, of which $30 \%$ is accounted for by crop production (FS DETEA, 2009). The need for water resulted in the construction of 412 impoundments that cover a combined surface area of $147677 \mathrm{ha}$. Due to the seasonality of rainfall and water released from dams for irrigation, the water levels of most dams fluctuate seasonally with periods of sharp increase in capacity, followed by periods of gradual or sharp decrease in water level.

The fish fauna of the OSRS is known for its low species diversity. Fish communities in Free State dams are dominated by 4 large cyprinids, namely Orange River mudfish Labeo capensis, moggel Labeo umbratus, L. aeneus, C. carpio, and the sharptooth catfish Clarias gariepinus (Barkhuizen, 2015). These fish are mostly targeted from the shoreline by angling with rod-and-reel and baited hooks as described for the Gariep Dam recreational fishery by Ellender et al. (2009). This form of angling is nationally referred to as bank angling and some participants belong to angling clubs that are affiliated to the Free State Freshwater Bank Angling Association (FSFBAA).

\begin{tabular}{|c|c|}
\hline \multicolumn{2}{|c|}{$\begin{array}{l}\text { TABLE } 1 \\
\begin{array}{c}\text { Summary of the provisions and restrictions with regards to the conservation and utilisation of freshwater fish in the Free State } \\
\text { Province according to the NCO (1969) and NCR (1983) as amended on } 17 \text { March } 1995\end{array}\end{array}$} \\
\hline Aspect & Notes \\
\hline Angling licence & $\begin{array}{l}\text { All anglers must be in possession of a valid angling licence when fishing. An angling licence costs } 40 \text { ZAR } \\
\text { and is valid for a period of } 1 \text { year, i.e. }, 1 \text { January until } 31 \text { December. Private landowners, their families and } \\
\text { employees are exempted from having an angling licence when angling off-channel impoundments on farm } \\
\text { land. }\end{array}$ \\
\hline Access & Permission must be obtained prior to entering any angling area. \\
\hline Restrictions & $\begin{array}{l}\text { Restrictions may be put in place for the catch of certain species during certain periods. Spawning fish, their } \\
\text { ova and fry and spawning areas may not be disturbed and these areas may not be entered into. }\end{array}$ \\
\hline Gear & $\begin{array}{l}\text { Anglers may only use } 2 \text { lines to which no more than } 2 \text { hooks with natural bait, } 2 \text { artificial flies or } 1 \text { artificial } \\
\text { lure or spoon, are attached. No jigging may be done and the setting of a long line is prohibited. Feeding } \\
\text { (ground bait) and angling places may not be marked. }\end{array}$ \\
\hline $\begin{array}{l}\text { Possession of fish } \\
\text { nets and traps }\end{array}$ & $\begin{array}{l}\text { With the exception of keep-nets and landing nets, only people with the necessary permits and } \\
\text { authorisation may sell, or be in possession of, any type of nets. }\end{array}$ \\
\hline $\begin{array}{l}\text { Import, sell and } \\
\text { release of live fish }\end{array}$ & Prohibited unless an approved permit has been issued by the FS DESTEA. \\
\hline Bag and size limits & $\begin{array}{l}\text { No angler may catch and keep more than } 10 \text { smallmouth yellowfish Labeobarbus aeneus which are larger } \\
\text { than } 450 \mathrm{~mm} \text { per day. All L. aeneus smaller than } 450 \mathrm{~mm} \text { must be released. Immediate catch-and-release is } \\
\text { applicable for largemouth yellowfish Labeobarbus kimberleyensis and none may be kept or killed. No more } \\
\text { than } 6 \text { trout larger than } 300 \mathrm{~mm} \text { may be caught and kept per day [this was only applicable at Sterkfontein } \\
\text { Dam where trout was stocked]. There are no further bag or size limits for the other fish species occurring } \\
\text { in the Free State Province. }\end{array}$ \\
\hline Bait & No live fish may be used as bait. \\
\hline $\begin{array}{l}\text { Angling } \\
\text { tournaments }\end{array}$ & $\begin{array}{l}\text { May only be arranged and presented after an official permit has been issued. During 2014/2015 a permit } \\
\text { cost } 100 \text { ZAR for an angling club to host tournaments. This permit was valid for a period of } 1 \text { year. Only } \\
\text { anglers in possession of valid angling licences are allowed to partake in angling tournaments. }\end{array}$ \\
\hline
\end{tabular}




\section{Angling participation}

Angling licences are sold at most offices of provincial nature reserves and resorts, the head office of the FS DESTEA in Bloemfontein and historically at a few retail stores. Duplicates of angling licences are kept in the licence books. Unfortunately, statistics on licences have never been compiled and records were only available in hard copy. After an initial investigation of the offices where angling licences were sold, data on licence sales were obtained for the 2013 and 2014 calendar years. Data regarding the number of anglers and angling clubs affiliated with the FSFBAA for the period January 2013 until December 2014 were obtained from the executive committee of the association.

\section{Tournament catch data}

Key informant interviews with angling club members were used to provide an understanding of the organisational structure of tournament angling. In summary, angling tournaments are controlled by the constitution and rules of the FSFBAA with regard to tournament participation and enforcement of specific rules regarding the duration, equipment, zoning of angling areas, and allocation of points based on the number and weight of fish caught. With regard to the allocation of points, an important consideration is that the number and weight of fish caught during tournaments is restricted to fish weighing more than $150 \mathrm{~g}$. Smaller fish are not counted but are added to the total weight of the total catch. Angling tournament catch records were obtained as a hard copy at the permit office in Bloemfontein and digitized.

The data were aggregated for all anglers taking part in a tournament and include the total catch as the number of fish (>150 g) and the total catch by weight of all fish, the number of participants and the total number of hours fished. These data allowed for the determination of species composition and catch per unit effort (CPUE), expressed as fish.angler ${ }^{-1} \cdot$ day $^{-1}$ and kg.angler ${ }^{-1}$. day ${ }^{-1}$ for each tournament, and an estimate of the probability of an angler catching a fish using the methods of Hargrove et al. (2015). It is important to note that for tournaments each angler is allowed to use 2 rods simultaneously.

\section{RESULTS}

\section{Angling participation}

In total, 8256 angling licences were sold in the Free State Province in 2013 and 7710 during 2014. Monthly sales of angling licences in the Free State Province are presented in Fig. 1. Licence sales were highest during the summer (December-January) and Easter (March/April) school holiday periods and lowest in winter (May-August) (Fig. 1). According to the membership records of the 30 FSFBAA-affiliated angling clubs, there were 804 and 748 club-affiliated anglers in the Province in 2013 and 2014, respectively. When expressed as a percentage of total licence sales, affiliated club anglers comprise about $10 \%$ of recreational anglers licensed to fish in the Free State Province.

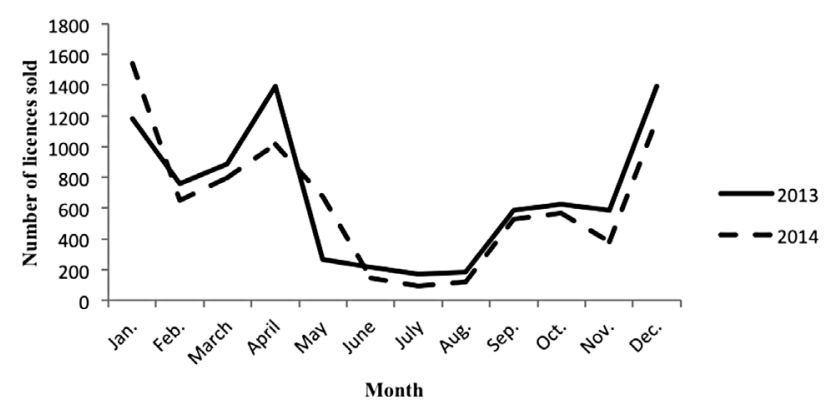

Figure 1

Number of angling licences sold in the Free State Province during 2013 and 2014

\section{Tournament data}

Data were available for 4796 tournaments held on 17 dams between 1974 and 2014. This was an average of 120 tournaments a year over the 40 -year assessment period. A summary of the physical characteristics of these impoundments and available data is presented in Table 2 and the location of the dams and the nearest urban areas is presented in Fig. 2. The distribution of tournament effort between impoundments is summarised in Table 3. On average, there are 182 tournaments held each year where anglers expended a mean ( \pm S.E.) effort of $4281 \pm 923$ angler.days ${ }^{-1} \cdot$ year $^{-1}$. The length of angling tournaments was $9.2 \pm 0.6 \mathrm{~h}$. During tournaments $64 \%$ of anglers weighed at least $1 \mathrm{fish}$ and the average CPUE in terms of number of fish was $3.9 \pm 0.7$ fish $\cdot$ angler $^{-1}$. day ${ }^{-1}$. The average CPUE in terms of the weight of the catch was $3.3 \pm 0.4 \mathrm{~kg}$.angler ${ }^{-1}$. day $^{-1}$ Preliminary analysis of CPUE data did not detect any consistent trends with age, water level, distance from the nearest town, and population size within the urban area. As a result, data for all years were grouped for comparison. Mean CPUE was surprisingly consistent between impoundments with only the CPUE from Bloemhof Dam being significantly higher than that of other impoundments (Kruskall Wallis non-parametric ANOVA, $p<0.05$; Table 3).

The most anglers participated in angling tournaments held at Bloemhof Dam, followed by Rustfontein, Vaal, Koppies and Krugersdrift Dams, which also hosted the most tournaments (Table 3). Krugersdrift and Rustfontein Dams are situated close to the Mangaung Metropolitan Municipality while Koppies Dam is preferred by angling clubs in the Northern Free State as a tournament venue. Because of its large surface area and close proximity to the Gauteng Province, the Vaal Dam was also one of the most frequented tournament angling venues.

The total number of tournament angling days, based on data available from 1974 to 2014, is summarised in Fig. 3.

There was a general increase in the number of tournament days between 1974 and 2000. Gaps in the data from 1994 to 2014 are the result of inconsistencies in record keeping and data loss at the permit office. Data for 2013 and 2014 are, however, accurate as these were collected and compiled by LM Barkhuizen. This indicates a general decline of tournament angling effort in the Free State Province between 2000 and 2014. 


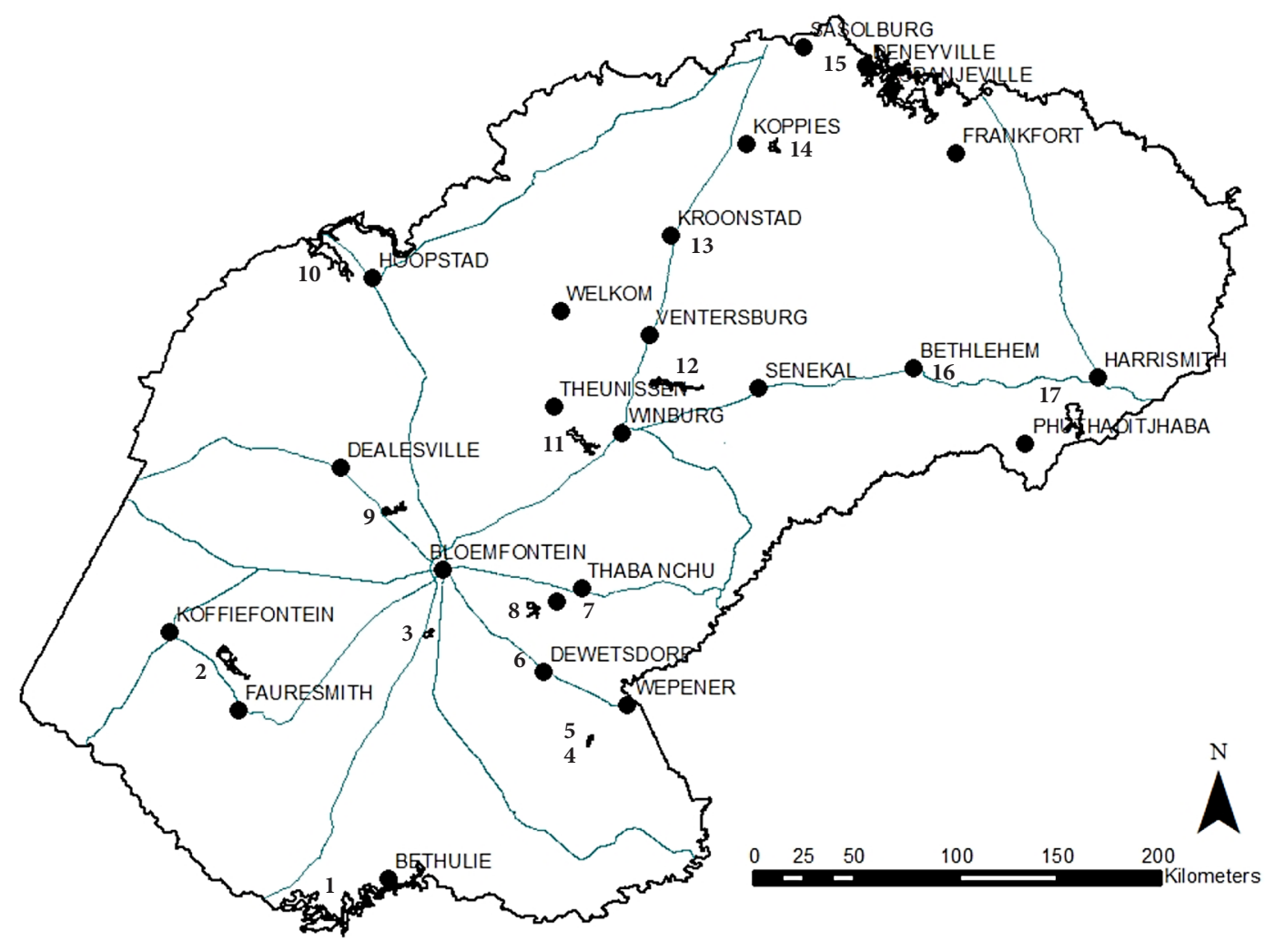

Figure 2

Location of important dams for recreational bank angling and their location within the Free State Province. 1 - Gariep; 2 - Kalkfontein; 3 - Tierpoort; 4 - Welbedacht; 5 - Knellpoort; 6 - Jimmie Roos; 7 - Moutloatsi Setlogelo; 8 - Rustfontein; 9 - Krugersdrift; 10 - Bloemhof; 11 - Erfenis; 12 - Allemanskraal; 13 - Bloemhoek; 14 - Koppies; 15 - Vaal; 16 - Sol Plaatjie; 17 - Sterkfontein.

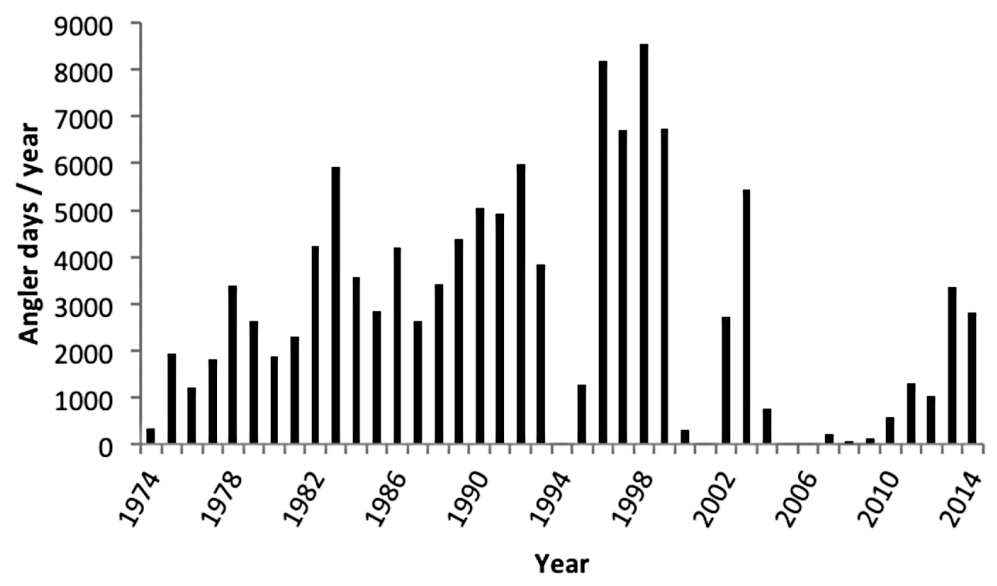

Figure 3

Total number of angling days based on angling tournament records of 17 impoundments in the Free State Province from 1974-2014 


\begin{tabular}{|c|c|c|c|c|c|c|c|c|c|}
\hline & & $\begin{array}{l}\text { Physi } \\
\text { catch da }\end{array}$ & $\begin{array}{l}\text { al cha } \\
\text { a for }\end{array}$ & $\begin{array}{l}\text { acteristi } \\
\text { ams loca }\end{array}$ & $\begin{array}{l}\text { TAB } \\
\text { and sur } \\
\text { d in the }\end{array}$ & $\begin{array}{l}2 \\
\text { mary of available tournament } \\
\text { ree State Province, South Afri }\end{array}$ & & & \\
\hline Dam & $\begin{array}{c}\text { Constr. } \\
\text { year }\end{array}$ & SA (ha) & $\begin{array}{l}\text { MD } \\
(\mathrm{m})\end{array}$ & $\begin{array}{l}\text { Z.D. } \\
(\mathrm{cm})\end{array}$ & $\begin{array}{c}\text { CON } \\
(\mu \mathrm{S} / \mathrm{m})\end{array}$ & Nearest town & $\begin{array}{l}\text { DNT } \\
(\mathrm{km})\end{array}$ & $\begin{array}{c}\text { Years of data } \\
\text { available }\end{array}$ & \begin{tabular}{|c|} 
Competitions \\
(n)
\end{tabular} \\
\hline Allemanskraal & 1960 & 2667 & 6.7 & 16 & 238 & Ventersburg & 22 & 30 & 252 \\
\hline Bloemhoek & 1995 & 370 & 7.1 & 31 & 333 & Kroonstad & 3 & 6 & 80 \\
\hline Bloemhof & 1970 & 23067 & 5.5 & 29 & 590 & Bloemhof & 1.3 & 36 & 749 \\
\hline Erfenis & 1960 & 3291 & 6.5 & 16 & 266 & Theunissen & 15 & 20 & 64 \\
\hline Gariep & 1971 & 35216 & 15.2 & 27 & 119 & Gariep Dam & 2 & 8 & 48 \\
\hline Jimmie Roos & 1920 & 115 & 3.1 & 21 & 422 & Dewetsdorp & 15 & 10 & 23 \\
\hline Kalkfontein & 1938 & 3769 & 6.9 & 33 & 591 & Koffiefontein & 23 & 23 & 98 \\
\hline Knellpoort & 1989 & 977 & 14 & 30 & 165 & Wepener & 15 & 4 & 5 \\
\hline Koppies & 1911 & 1439 & 2.8 & 20 & 481 & Koppies & 12 & 35 & 655 \\
\hline Krugersdrift & 1970 & 1853 & 3.6 & 33 & 598 & Bloemfontein & 42 & 36 & 891 \\
\hline Moutloatsi Setlogelo & 1981 & 250 & 5.6 & 20 & 279 & Thaba Nchu & 7 & 5 & 20 \\
\hline Rustfontein & 1955 & 1159 & 6.2 & 29 & 265 & Bloemfontein & 40 & 35 & 865 \\
\hline Sol Plaatjie & 1968 & 356 & 4.4 & 45 & 91 & Bethlehem & 8 & 8 & 84 \\
\hline Sterkfontein & 1980 & 6937 & 37.7 & $>200$ & 59 & Harrismith & 16 & 9 & 63 \\
\hline Tierpoort & 1923 & 911 & 3.7 & 25 & 418 & Bloemfontein & 35 & 4 & 9 \\
\hline Vaal & 1938 & 32275 & 7.9 & 27 & 204 & Oranjeville and Deneysville & 1.5 & 34 & 861 \\
\hline Welbedacht & 1973 & 1018 & 1 & 10 & 298 & Wepener & 27 & 6 & 29 \\
\hline
\end{tabular}

Constr. year = construction year; $S A=$ surface area; $M D=$ mean depth; $Z . D .=$ Secchi depth; Con $=$ conductivity; DNT = distance from nearest town

\begin{tabular}{|c|c|c|c|c|c|c|c|c|c|c|c|}
\hline \multirow[b]{3}{*}{ Dam } & \multirow{3}{*}{$\begin{array}{l}\begin{array}{r}\text { Summary } \\
\text { effort }\end{array} \\
\begin{array}{|c|}\text { Sample } \\
\text { size }\end{array} \\
\text { Years } \\
\end{array}$} & \multirow{3}{*}{$\begin{array}{c}\begin{array}{c}\text { Frequency } \\
\left(\text { events·year }^{-1}\right)\end{array} \\
\text { Mean } \\
\end{array}$} & \multirow{3}{*}{\multicolumn{2}{|c|}{$\begin{array}{l}\text { TABL } \\
\text { quency } \\
\text { ments i } \\
\text { fort } \\
\left.\text {-year }{ }^{-1}\right) \\
\text { S.E. }\end{array}$}} & \multirow{2}{*}{\multicolumn{2}{|c|}{$\begin{array}{l}\text { angler effort, su } \\
\text { the Free State P } \\
\begin{array}{c}\text { Tournament } \\
\text { duration (hours) }\end{array}\end{array}$}} & \multirow{3}{*}{\begin{tabular}{|c|} 
Success \\
$(\%)$ \\
\end{tabular}} & \multirow{2}{*}{\multicolumn{2}{|c|}{\begin{tabular}{|c|} 
CPUE \\
(fish.angler ${ }^{-1} \cdot$ day $^{-1}$ )
\end{tabular}}} & \multirow{2}{*}{\multicolumn{2}{|c|}{$\begin{array}{c}\text { CPUE } \\
\left(\mathrm{kg} \cdot \text { angler }^{-1} \cdot \text { day }^{-1}\right)\end{array}$}} \\
\hline & & & & & & & & & & & \\
\hline & & & & & Mean & S.E. & & Mean & S.E. & Mean & S.E. \\
\hline Allemanskraal & 30 & 8 & 216 & 40 & 7.2 & 0.2 & 69 & 2.9 & 0.4 & 2.8 & 0.5 \\
\hline Bloemhoek & 6 & 13 & 279 & 56 & 7.4 & 0.2 & 51 & 1.8 & 0.5 & 0.9 & 0.2 \\
\hline Bloemhof & 36 & 21 & 622 & 95 & 7.7 & 0.1 & 81 & 6.5 & 0.7 & 7.2 & 0.8 \\
\hline Erfenis & 20 & 3 & 74 & 12 & 9.3 & 0.7 & 55 & 2.3 & 0.4 & 3.7 & 0.8 \\
\hline Gariep & 8 & 6 & 92 & 28 & 8.0 & 0.2 & 74 & 3.4 & 0.8 & 3.7 & 1.1 \\
\hline Jimmie Roos & 10 & 2 & 42 & 18 & 8.2 & 0.1 & 66 & 5.6 & 2.3 & 3.5 & 1.0 \\
\hline Kalkfontein & 23 & 4 & 89 & 17 & 9.0 & 0.6 & 66 & 2.8 & 0.4 & 3.0 & 0.4 \\
\hline Knellpoort & 4 & 1 & 18 & 5 & 14.5 & 4.3 & 64 & 13.5 & 7.8 & 5.9 & 3.1 \\
\hline Koppies & 35 & 19 & 507 & 107 & 8.2 & 0.1 & 67 & 2.8 & 0.3 & 2.1 & 0.2 \\
\hline Krugersdrift & 36 & 25 & 502 & 77 & 16.5 & 3.3 & 67 & 3.4 & 0.4 & 4.1 & 0.7 \\
\hline Moutloatsi Setlogelo & 5 & 4 & 68 & 23 & 7.5 & 0.3 & 84 & 5.6 & 2.2 & 5.1 & 1.6 \\
\hline Rustfontein & 35 & 25 & 604 & 76 & 9.0 & 0.5 & 68 & 3.4 & 0.3 & 2.9 & 0.2 \\
\hline Sol Plaatjie & 8 & 11 & 193 & 76 & 7.9 & 0.1 & 60 & 2.2 & 0.8 & 1.5 & 0.7 \\
\hline Sterkfontein & 9 & 7 & 147 & 41 & 7.0 & 0.4 & 57 & 3.4 & 0.8 & 2.0 & 0.4 \\
\hline Tierpoort & 4 & 2 & 42 & 18 & 9.4 & 1.1 & 61 & 3.6 & 1.7 & 5.1 & 2.3 \\
\hline Vaal & 34 & 25 & 599 & 89 & 9.0 & 0.2 & 67 & 3.3 & 0.5 & 2.4 & 0.3 \\
\hline Welbedacht & 6 & 5 & 122 & 47 & No data & No data & 28 & 0.5 & 0.2 & 0.7 & 0.2 \\
\hline All dams & & 118 & 248 & 54 & 9.1 & 0.7 & 64 & 3.9 & 0.7 & 3.3 & 0.4 \\
\hline
\end{tabular}

S.E. = standard error 
Tournament catches were dominated by C. carpio which made up between 42 and $98 \%$ of the weight and 9 and $99 \%$ of the total catch in number. Overall this species comprised $81 \%$ of the weight and $77 \%$ of the numbers of all fish landed by tournament anglers making it the most important angling species. Other important angling species were L. capensis and C. gariepinus (see Table 4).

\section{DISCUSSION}

This assessment demonstrates that recreational angling, including tournament angling, continues to be an important fisheries activity in the Free State Province of South Africa, although both tournament and licence sale data demonstrate that participation appears to have decreased in recent years. According to McCafferty et al. (2012), there are unfortunately few recreational angling data available for comparison. Data that are available are mostly too old or cover too wide a geographical area for meaningful assessment. Historical data do, however, illustrate the rapid increase in participation in recreational angling from the 1950s to the 1970s. Du Plessis and Le Roux (1965), for example, reported an increase in angling licence sales from 28000 in 1951 to 49000 in 1957 and 61380 in 1963 in the former Transvaal Province, which today would include Limpopo, Mpumalanga, Gauteng and the North West Provinces. Subsequent to their report, the number of licences increased to 68000 in 1964 (Skelton, 1993), 100000 in 1970 (Mulder, 1971) and 117093 in 1978 (Cadieux, 1980). Unfortunately, no subsequent assessments were undertaken to enable a more recent comparison. Similarly, in the Free State Province, the only available historic information on the number of recreational anglers is from Marshall (1972), who reported that there were 23708 recreational anglers in the former Orange Free State Province during 1970 and 32 065 in 1971. The current (2014) enumeration of licence sales demonstrated that there were 7710 licensed recreational anglers in the Province which indicates a 76\% decrease in the number of licensed recreational anglers since 1971.
Evidence from licence sales was supported by a similar $67 \%$ decrease in reported tournament effort, from a maximum of 8548 tournament days in 1998 to 2828 days in 2014 . The applicable regulations for hosting angling tournaments and for anglers to obtain angling licences according to the Nature Conservation Ordinance have not changed and the decreases are very likely an indication of a decrease in the number of recreational anglers and not a change in legislation.

Estimates based on licence sales may, however, be biased. For example, all anglers that are affiliated with angling clubs are obliged to obtain an angling licence while the majority of subsistence anglers are unlicensed (LM Barkhuizen, pers. obs.). These observations are supported by Ellender et al. (2009), who, on the basis of 750 interviews conducted with recreational and subsistence anglers on Gariep Dam, reported that most recreational but few of the approx. 450 subsistence fishers were in possession of an angling licence. As subsistence angling constituted $60 \%$ of angling effort on that dam, licence sale data alone are now unlikely to provide an accurate indication of utilisation by anglers. This is unfortunate as subsistence angling is now common in many South African impoundments (Weyl et al., 2007; Ellender et al., 2010a; Tapela et al., 2015) and licensing would not only legitimize access, but also allow for a better quantification of this sector.

As angling provides important food security and provides an economic safety-net for subsistence anglers (Ellender et al., 2009; Tapela et al., 2015), a comprehensive survey to assess for total angling participation is therefore an urgent requirement if the importance of angling to rural communities is to be estimated. This is particularly important because the value of these fisheries to subsistence and livelihoods needs to be recognised as all attempts to develop formal commercial fisheries have failed (Barkhuizen et al., 2016).

In terms of target species, it is interesting to note that, for bank anglers, alien C. carpio are the most important component in the catch. Du Plessis and Le Roux (1965) noted that the primary target species for anglers in the former Transvaal Province was C. carpio, Mozambique tilapia

\begin{tabular}{|c|c|c|c|c|c|c|c|c|c|c|}
\hline \multirow{3}{*}{ Locality } & \multicolumn{8}{|c|}{ 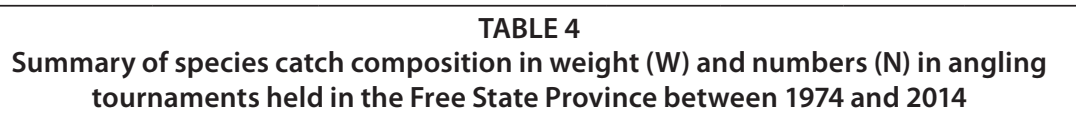 } & \multirow{2}{*}{\multicolumn{2}{|c|}{ Others }} \\
\hline & \multicolumn{2}{|c|}{ Total catch } & \multicolumn{2}{|c|}{ Carp } & \multicolumn{2}{|c|}{ Catfish } & \multicolumn{2}{|c|}{ Mudfish } & & \\
\hline & W & $\mathrm{N}$ & $\% W$ & $\% \mathrm{~N}$ & $\% \mathrm{~W}$ & $\% \mathrm{~N}$ & $\% W$ & $\% \mathrm{~N}$ & $\% W$ & $\% \mathrm{~N}$ \\
\hline Allemanskraal & 14868 & 17445 & 55.8 & 53.7 & 33.1 & 27.1 & 7.6 & 14.6 & 3.4 & 4.6 \\
\hline Bloemhoek & 1102 & 2289 & 77 & 65.7 & 2.9 & 2.1 & 19.9 & 32.1 & 0.2 & 0 \\
\hline Bloemhof & 158068 & 140539 & 91.1 & 91.7 & 7.5 & 5.7 & 0.9 & 1.7 & 0.6 & 0.9 \\
\hline Erfenis & 5183 & 3254 & 42.2 & 46.2 & 54.1 & 43.8 & 1.6 & 4.9 & 2.2 & 5.2 \\
\hline Gariep & 3289 & 2535 & 83.6 & 87.7 & 13 & 8.6 & 1 & 1.6 & 2.4 & 2.1 \\
\hline Jimmie Roos & 1382 & 1467 & 97.8 & 95 & 0.9 & 2.3 & 0.5 & 1.3 & 0.7 & 1.4 \\
\hline Kalkfontein & 5898 & 5594 & 84.1 & 83.7 & 7.2 & 5.9 & 3 & 3.9 & 5.8 & 6.5 \\
\hline Knellpoort & 504 & 1155 & 87.4 & 88.6 & 4.9 & 2.7 & 7.2 & 8.5 & 0.4 & 0.3 \\
\hline Koppies & 36993 & 45878 & 46.1 & 47.3 & 18.1 & 10.1 & 30.1 & 35.7 & 5.8 & 7 \\
\hline Krugersdrift & 68539 & 63829 & 88 & 90.7 & 10.5 & 6.3 & 1.1 & 2.2 & 0.5 & 0.8 \\
\hline Moutloatsi Setlogelo & 1469 & 1452 & 73.8 & 60.8 & 15.6 & 5.9 & 10.5 & 33.3 & 0 & 0 \\
\hline Rustfontein & 59599 & 67875 & 81 & 75.2 & 5.3 & 4.7 & 11.5 & 17.2 & 2.1 & 2.9 \\
\hline Sol Plaatje & 1433 & 1849 & 57.1 & 49.5 & 17.5 & 17.1 & 24.1 & 32.6 & 1.3 & 0.8 \\
\hline Sterkfontein & 3913 & 6629 & 20.8 & 9.4 & 5.1 & 2.2 & 65.1 & 84.1 & 9 & 4.3 \\
\hline Tierpoort & 1210 & 878 & 97.7 & 98.7 & 2.3 & 0.9 & 0 & 0.1 & 0 & 0.2 \\
\hline Welbedacht & 657 & 471 & 34.1 & 6.6 & 65 & 90.9 & 0.4 & 0.6 & 0.6 & 1.9 \\
\hline Vaal & 50018 & 66122 & 77.7 & 70.8 & 7.5 & 8.6 & 10.9 & 17.1 & 3.7 & 3.4 \\
\hline TOTAL & 414125 & 429261 & 80.5 & 77.2 & 10.2 & 7.8 & 7.3 & 12.5 & 1.9 & 2.5 \\
\hline
\end{tabular}


Oreochromis mossambicus and C. gariepinus. Cochrane (1987), working on the eutrophic Hartbeespoort Dam, estimated that $65 \%$ of the $695 \mathrm{t}$ annual average harvest by recreational anglers was C. carpio. This is supported by tournament data for the Free State Province, where C. carpio contributed 81\% of the total weight and $77 \%$ of the total numbers of all fish landed (Table 4). The findings from tournament data were surprisingly consistent with the results of a comprehensive creel survey comprising more than 700 anglers' interviews and catch inspections at Gariep Dam, and which found that angler catches comprised mainly of C. carpio (74\%), followed by L. capensis (13\%) and L. aeneus (8\%) (Ellender et al., 2009; 2010a; 2010b).

\section{Considerations for fisheries development}

Based on the number of angling licences sold at provincial nature reserves and resorts and where angling tournaments were held, the most important impoundments in the Free State Province for bank angling are Allemanskraal, Bloemhof, Erfenis, Koppies, Krugersdrift and, historically, Rustfontein. All of these impoundments' surface areas at full supply level, except for Rustfontein Dam, are larger than 1400 ha.

Impoundments located close to urban areas (e.g. Krugersdrift, Rustfontein, Allemanskraal, Erfenis, Koppies and Vaal Dams) were visited by the most recreational anglers. Cadieux (1980) also noted that the most popular angling venues in the former Transvaal Province were those close to major urban areas. The popularity of Hartbeespoort Dam as an angling venue was attributed by Cochrane (1987) to its close proximity to two major urban areas, namely Pretoria and Johannesburg, in the Gauteng Province.

No quantitative assessment has ever been done on the economic value of recreational bank angling in the Free State Province. Based on assessments of the value of recreational fisheries elsewhere in South Africa (see Du Plessis and Le Roux, 1965; Cadieux, 1980; Brand et al., 2009; Du Preez and Lee, 2010; ASA, 2016), the contribution of this activity to the economy of the Free State Province is likely to be considerable. In addition, angling for subsistence use contributes considerably to food security in some localities (see Ellender et al., 2010a). For these reasons, it is important that angling is recognised in the development of fisheries. This is particularly important as anglers have become vocal opponents to legislative and developmental projects which they feel might impinge negatively on them. As angling licences do provide an opportunity to enumerate participation, it is highly recommended that an effort be made to license all anglers in the Free State Province such that an estimate of total participation in this sector can be quantified.

\section{ACKNOWLEDGEMENTS}

LMB thanks the FS DESTEA for support during the study on fish and inland fisheries in the Orange-Senqu River Basin. OLFW would like to thank the National Research Foundation (Grant No.77444); the DST/NRF Centre of Excellence for Invasion Biology and the Water Research Commission (WRC) solicited and funded project 'Baseline and scoping study on the development and sustainable use of storage dams for inland fisheries and their contribution to rural livelihoods' (WRC Project No. K5/1957/4) for support.

\section{REFERENCES}

ASA (American Sportfishing Association) (2016) URL: http://www. ASAfishing.org (Accessed 12 September 2016).

BARKHUIZEN LM (2015) An assessment of fish and fisheries in impoundments in the Upper Orange-Senqu and lower Vaal River Basin. PhD thesis, University of the Free State, Bloemfontein.

BARKHUIZEN LM, WEYL OLF and VAN AS JG (2016) A qualitative and quantitative analysis of historic commercial fisheries in the Free State Province in South Africa. Water SA 42 (4) 601-605. https://doi.org/10.4314/wsa.v42i4.10

BRAND M, MAINA J, MANDER M and O'BRIEN G (2009) Characterisation of the social and economic value of the use and associated conservation of the yellowfishes in the Vaal River. WRC Report No. KV 226/09. Water Research Commission, Pretoria.

BREMNER JM, ROGERS J and WILLIS JP (1990) Sedimentological aspects of the 1988 Orange River floods. Trans. R. Soc. S. Afr. 47 247-294. https://doi.org/10.1080/00359199009520243

BRITZ PJ, HARA MM, WEYL OLF, TAPELA BN and ROUHANI Q (2015) Scoping study on the development and sustainable utilisation of inland fisheries in South Africa. Volume 1: Scoping Report. WRC Report No. TT 615-1-14. Water Research Commission, Pretoria.

CADIEUX JJ (1980) Freshwater angling in the Transvaal: environmental and economic impact. S. Afr. J. Sci. 76 (11) 492-493.

COCHRANE KL (1987) The biomass and yield of the dominant fish species in Hartbeespoort Dam, South Africa. Hydrobiologia 146 89-96. https://doi.org/10.1007/BF00007581

COMPTON JS, HERBERT CT, HOFFMAN MT, SCHNEIDER RR and STUUT J (2010) A tenfold increase in the Orange River mean Holocene mud flux: implications for soil erosion in South Africa. The Holocene 20 (1) 115-122. https://doi. org/10.1177/0959683609348860

COOKE SJ, LAPOINTE NWR, MARTINS EG, THIEM JD, RABY GD, TAYLOR MK, BEARD TD and COWX IG (2013) Failure to engage the public in issues related to inland fishes and fisheries strategies: strategies for building public and political will to promote meaningful conservation. J. Fish Biol. 83 997-1018. https://doi. org/10.1111/jfb.12222

DU PLESSIS SS and LE ROUX PJ (1965) Sport fisheries in river development with reference to the Orange River Scheme. S. Afr. J. Sci. 61 (3) 137-146.

DU PREEZ M and LEE DE (2010) The contribution of trout fly fishing to the economy of Rhodes, North Eastern Cape, South Africa. Dev. South. Afr. 27 (2) 241-253. https://doi. org/10.1080/03768351003740654

ELLENDER BR, WEYL OLF and WINKER H (2009) Who uses the fishery resources in South Africa's largest impoundment? Characterising subsistence and recreational fishing sectors on Lake Gariep. Water SA 35 677-682. https://doi.org/10.4314/wsa. v35i5.49194

ELLENDER BR, WEYL OLF, WINKER H and BOOTH AJ (2010a). Quantifying the annual fish harvest from South Africa's largest freshwater reservoir. Water SA 36 45-51. https://doi.org/10.4314/ wsa.v36il.50906

ELLENDER BR, WEYL OLF, WINKER H, STELZHAMMER H and TRAAS GRL (2010b) Estimating angling effort and participation in a multi-user, inland fishery in South Africa. Fish. Manage. Ecol. 17 19-27.

FS DETEA. (2009). Free State Environmental Outlook: A report on the state of the environment. Free State Department of Economic Development, Tourism and Environmental Affairs, Bloemfontein.

HARGROVE JS, WEYL OLF, ALLEN MS and DEACON NR (2015) Using angler tournament data to rapidly assess the invasion status of alien sport fishes (Micropterus spp.) in southern Africa. PLoS ONE 10 (6) E0130056. Doi: 10.137/journal.pone.0130056. https://doi.org/10.1371/journal.pone.0130056

MARSHALL RD (1972) An investigation into the biology of Labeo umbratus (A. Smith) Boulenger, 1841. Progress Report No. 1, Nature Conservation, Orange Free State Provincial Administration.

McCAFFERTY JR, ELLENDER BR, WEYL OLF and BRITZ P (2012) The use of water resources for inland fisheries in South Africa. Water SA 38 327-344. https://doi.org/10.4314/wsa.v38i2.18 
MULDER PFS (1971) 'n Ekologiese studie van die hengelvisfauna van die Vaalriviersisteem, met spesiale verwysing na Barbus kimberleyensis Gilchrist and Thompson. Provinsiale Vissery Instituut, Lydenburg.

NCO (Nature Conservation Ordinance) (1969) Nature Conservation Ordinance no. 8 of 1969. Orange Free State Provincial Government, Bloemfontein.

NCR (Nature Conservation Regulations) (1983) Nature Conservation Regulations, Administrator's Notice184 of 12 August 1983. Orange Free State Provincial Government, Bloemfontein.

OPPERMAN RWJ (1965) The recreational potential of the Orange River Project. S. Afr. J. Sci. 61 (3) 147-151.

SASACC (South African Sport Anglers and Casting Confederation) (2016) URL: http://www.sasacc.co.za (Accessed 31 October 2016).

SKELTON PH (1993) ' $n$ Volledige Gids tot die Varswatervisse van Suider-Afrika. Southern Boekuitgewers, Halfweghuis. 387 pp.

STATS SA (Statistics South Africa) URL: http://statssa.gov.za (Accessed 25 July 2016).

TAPELA B, BRITZ PJ and ROUHANI Q (2015) Scoping study on the development and sustainable utilisation of inland fisheries in South Africa. Volume 2. Case studies of small-scale inland fisheries. WRC Report No. TT 615-1-14. Water Research Commission, Pretoria.
TAYLOR CG, WEYL OLF, COWLEY PD and ALLEN MS (2015) Dispersal and population-level mortality of Micropterus salmoides associated with catch and release tournament angling in a South African reservoir. Fish. Res. 16237 - 42. https://doi.org/10.1016/j. fishres.2014.09.014

WEYL OLF and COWLEY PD (2015) Fisheries in subtropical and temperate regions of Africa. In: Craig JF (ed.) Freshwater Fisheries Ecology. John Wiley \& Sons, Chichester, UK.

WEYL OLF, POTTS W, ROUHANI Q and BRITZ P (2007) The need for inland fisheries policy in South Africa: A case study of the North West Province. Water SA 33 1-8.

WEYL OLF, BOOTH AJ, WINKER H, TRAAS GRL, MCCAFFERTY JR, PEEL RA and WARTENBERG R (2010) Assessment of the fishery potential for alien species on Darlington Dam. Sundays River Freshwater Fish Research Project. Report No. 5. 59 pp.

YATES JH (1963) The Orange Free State. In: Harrison AC, ShorttSmith KE, Yates JH, Jubb RA, Rushby G and Flamwell CT (eds) (1963) Freshwater Fish and Fishing in Africa. Nelson Publishers, Johannesburg. 96-101. 